\title{
FORMULASI SEDIAAN GEL EKSTRAK ETANOL DAUN KALIANDRA (Calliandra surinamensis Benth) SEBAGAI ANTIBAKTERI
}

\author{
Yulita Ni Nyoman Tri Sukartiningsih), Hosea Jaya Edy ${ }^{1)}$, Jainer Pasca Siampa ${ }^{\text {1) }}$ \\ ${ }^{1)}$ Program Studi Farmasi FMIPA UNSRAT Manado, 95115
}

\begin{abstract}
Kaliandra Leaf (Calliandra surinamensis Benth) contains flavonoid compounds, saponins and tannins which are able to inhibit the antibacterial activity. This study aims to test the antibacterial effectiveness of gel preparation of ethanol extracts of kaliandra leaf to obtain the greatest formula, and prove the Kaliandra leaf gel preparation has good physical stability. This study uses a laboratory experimental method. Gel formula is made as many as 5 formulas with variations in the concentration of $2 \%, 3 \%, 4 \%, 5 \%$, and $6 \%$ of $w: v$. Kaliandra leaf extraction was carried out by maceration method using $96 \%$ ethanol. The antibacterial test of the ethanol extracts of Kaliandra leaf gel using the method of welling against Staphylococcus aureus bacteria produced a moderate inhibition of $7.0 \pm 0.63 \mathrm{~mm}$ at a concentration of $6 \%$. The physical evaluation of the preparation includes organoleptic test, homogeneity test, syneresis test, scatter power test, adhesion test, pH test, cycling test, and sterility test. All tests are carried out before and after the cycling test. The results of the study on the preparation fulfilled the physical evaluation requirements before and after the cycling test. It can be concluded that the concentration of $6 \%$ of ethanol extracts of Kaliandra leaves could be formulated as a gel preparation that is physically stable and has moderate antibacterial activity.
\end{abstract}

Keywords: Kaliandra (Calliandra surinamensis Benth), Gel preparations, Staphylococcus aureus antibacterial.

\begin{abstract}
ABSTRAK
Daun Kaliandra (Calliandra surinamensus Benth) mengandung senyawa flavonoid, saponin dan tannin yang mampu menghambat aktivitas antibakteri. Penelitian ini bertujuan untuk menguji efektivitas antibakteri sediaan gel ekstrak etanol daun Kaliandra untuk mendapatkan formula terbesar, serta membuktikan sediaan gel daun Kaliandra mempunyai stabilitas fisik yang baik. Penelitian ini menggunakan metode ekperimental laboratorium. Formula sediaan gel dibuat sebanyak 5 formula dengan variasi konsentrasi 2\%, 3\%, 4\%, 5\%, dan 6\% b/v. Ekstraksi daun Kaliandra dilakukan dengan metode maserasi menggunakan etanol 96\%. Penelitian uji antibakteri sediaan gel ekstrak etanol daun Kaliandra menggunakan metode sumuran pada bakteri

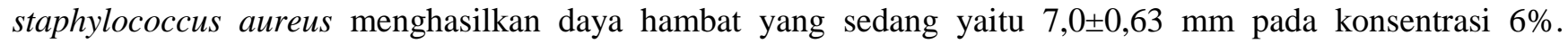
Evaluasi fisik sediaan meliputi uji organoleptik, uji homogenitas, uji sineresis, uji daya sebar, uji daya lekat, uji $\mathrm{pH}$, uji cycling test, dan uji sterilitas. Semua pengujian dilakukan sebelum dan sesudah cycling test. Hasil penelitian sediaan memenuhi persyaratan eveluasi fisik sebelum uji cycling test dan sesudah cycling test. Dapat disimpulkan pada kosentrasi 6\% ekstrak etanol daun Kaliandra dapat diformulasi sebagai sediaan gel yang stabil secara fisik dan memiliki aktivitas antibakteri yang sedang.
\end{abstract}

Kata kunci : Kaliandra (Calliandra surinamensis Benth), Sediaan Gel, Antibakteri Staphlococcous aureus. 
PHARMACON- PROGRAM STUDI FARMASI, FMIPA, UNIVERSITAS SAM RATULANGI,

Volume 8 Nomor 4 November 2019

\section{PENDAHULUAN}

Infeksi merupakan salah satu penyakit yang menjadi masalah utama kesehatan dan merupakan penyebab kematian utama hampir di seluruh Dunia. Penyebab utama terjadinya infeksi adalah adanya mikroorganisme patogen yang masuk dalam tubuh diantaranya adalah bakteri (Radji, 2011). Salah satu bakteri yang sering menyebabkan infeksi adalah Staphyloccus aureus (Jawetz et al., 2005).

Staphyloccus aureus merupakan bakteri coccus Gram Positif yang ditemukan sebagai flora normal pada kulit dan selaput lendir manusia (Jawetz et al., 2005). Bakteri Staphyloccus aureus juga dapat ditemukan pada udara dan lingkungan sekitar (Warsa, 1994).

Gel merupakan sediaan topikal yang mudah diaplikasikan pada kulit serta memiliki penampilan fisik yang menarik dibanding sediaan topikal lainnya (Wyatt, et al., 2001). Hal ini disebabkan karena sediaan gel memiliki kandungan air yang bersifat mendinginkan, menyejukkan, melembabkan, mudah penggunaannya, mudah berpenetrasi pada kulit, sehingga memberikan efek penyembuhan yang lebih cepat sesuai dengan basis yang digunakan (Ansel, 2005).

\section{METODOLOGI PENELITIAN}

\section{Waktu dan Tempat \\ Penelitian}

Penelitian ini dilaksanakan pada bulan Mei 2019 - Agustus 2019 di Laboratorium Penelitian Farmasi Lanjut dan Laboratorium Biologi Dasar, Fakultas Matematika dan Ilmu Pengetahuan Alam, Universitas Sam Ratulangi, Manado.

\section{Bentuk Penelitian}

Bentuk Penelitian ini menggunakan metode eksperimental untuk formulasi sediaan gel ekstrak etanol daun Kaliandra (Calliandra surinamensis Benth) sebagai antibakteri.

\section{Alat dan Bahan}

\section{Alat}

Alat-alat yang akan digunakan ialah alat-alat gelas, rotary evaporator, autoclave $\left(\mathrm{ALP}^{\circledR}\right)$, penjepit, pinset, oven, alumunium foil, timbangan analitik, blender (Philips), jarum ose, lampu spiritus, $\mathrm{pH}$ meter, toples maserasi, pot saleb, inkubator (MMM Gramoup $\left.^{\circledR}\right)$, Laminar air flow $\left(\mathrm{LAF}^{\circledR}\right)$, Colony Counter (Stuart Scientific ${ }^{\circledR}$ ), jangka sorong, mistar, ayakan, kaca preparat, kertas saring, pencadang, lemari pendingin, dan pipet mikro.

\section{Bahan}

Bahan-bahan yang digunakan ialah ekstrak daun Kaliandra, etanol 96\%, Nutrient agar, Karbopol 940, Gliserin, TEA, aquadest, gel Acnes ${ }^{\circledR}, \mathrm{NaCl} 0,9 \%$ dan bakteri Staphylococcus aureus.

\section{Prosedur Penelitian}

\section{Pengambilan Sampel}

Pengambilan sampel di Desa Sea, Kecamatan Pineleng, Kabupaten Minahasa. Bahan yang digunakan ialah bagian daun Kaliandra

\section{Identifikasi Sampel}

Identifikasi tanaman dilakukan di Laboratorium Taksonomi Tumbuhan, Jurusan Biologi, Fakultas Matematika dan 
PHARMACON- PROGRAM STUDI FARMASI, FMIPA, UNIVERSITAS SAM RATULANGI,

Volume 8 Nomor 4 November 2019

Ilmu Pengetahuan Alam, Universitas Sam Ratulangi Manado.

\section{Ekstraksi}

Pembuatan ekstrak etanol daun Kaliandra menggunakan metode maserasi. Serbuk Daun Kaliandra ditimbang sebanyak $400 \mathrm{~g}$ dimasukkan dalam toples, ditambahkan pelarut etanol $96 \%$ sebanyak $1600 \mathrm{~mL}$ didiamkan selama 3 hari sambil sesekali diaduk. Setelah 3 hari disaring dengan menggunakan kertas saring dan menghasilkan filtrat 1 dan debris 1 . Debris 1 yang ada kemudian direndam lagi (remaserasi) dengan pelarut yang sama selama 2 hari sambil sesekali diaduk. Setelah 2 hari, sampel disaring sehingga menghasilkan filtrat 2 dan debris 2 . Filtrat 1 dan filtrat 2 dicampurkan menjadi satu lalu dievaporasi menggunakan rotary evaporator sehingga diperoleh ekstrak kental. Dan kemudian dikerok dan di masukkan kedalam pot salep dan di timbang.

\section{Formulasi Sediaan Gel}

Formulasi sediaan gel ekstrak etanol daun Kaliandra dapat dilihat pada Tabel. 1 :

Tabel 1. Formulasi Sediaan Gel

\begin{tabular}{|c|c|c|c|c|c|c|}
\hline \multirow{2}{*}{ Bahan } & \multirow{2}{*}{ Fungsi } & \multicolumn{5}{|c|}{ Kosentrasi \% b/v } \\
\hline & & $\mathrm{F} 1$ & $\mathrm{~F} 2$ & F3 & $\mathrm{F} 4$ & F5 \\
\hline $\begin{array}{c}\text { Ekstrak } \\
\text { Kaliandr } \\
\text { a }\end{array}$ & $\begin{array}{l}\text { Bahan } \\
\text { aktif }\end{array}$ & 2 & 3 & 4 & 5 & 6 \\
\hline $\begin{array}{c}\text { Karbopo } \\
1940\end{array}$ & $\begin{array}{r}\text { Gelling } \\
\text { agent }\end{array}$ & 1 & 1 & 1 & 1 & 1 \\
\hline TEA & $\begin{array}{c}\text { Zat } \\
\text { pengemuls } \\
\mathrm{i}\end{array}$ & 6 & 6 & 6 & 6 & 6 \\
\hline Gliserin & Humektan & 1 & 1 & 1 & 1 & 1 \\
\hline Aquades & Pelarut & $\mathrm{ad}$ & $\mathrm{ad}$ & $\mathrm{ad}$ & $\mathrm{ad}$ & ad \\
\hline $\mathrm{t}$ & & 10 & 10 & 10 & 10 & 10 \\
\hline & & 0 & 0 & 0 & 0 & 0 \\
\hline & & $\mathrm{mL}$ & $\mathrm{mL}$ & $\mathrm{mL}$ & $\mathrm{mL}$ & $\mathrm{mL}$ \\
\hline
\end{tabular}

\section{Pembuatan Sediaan Gel}

Pembuatan gel ekstrak etanol daun Kaliandra dengan basis gel Karbopol 940. Karbopol ditimbang dan dilarutkan dengan aquadest \pm 24 jam hingga mengembang, kemudian di aduk cepat dalam wadah sampai terbentuk masa gel dan ditambahkan TEA. Setelah itu tambahkan Gliserin dan diaduk sampai homogen. Ekstrak daun Kaliandra ditimbang dan diaduk sampai larut. Ekstrak yang sudah larut dicampur sampai homogen ditambahkan aquadest 50 $\mathrm{ml}$, dan diaduk cepat menggunakan mixer sampai terbentuk masa gel. Untuk pembuatan gel dengan konsentrasi 3\%, 4\%, $5 \%$, dan $6 \%$ dilakukan dengan cara yang sama dan dimasukkan ke dalam wadah gel. Setelah dilakukan pembuatan sediaan gel maka dilakukan uji aktifitas antibakteri terhadap bakteri Staphylococcus aureus.

\section{Uji Aktivitas Antibakteri}

Uji aktivitas antibakteri terhadap sediaan gel ekstrak etanol daun Kaliandra menggunakan bakteri Staphylococcus aureus dengan cara difusi agar. 5 sumuran untuk setiap konsentrasi sediaan gel ekstrak etanol daun Kaliandra 2\%, $3 \%, 4 \%, 5 \%, 6 \%$ dan dua sumuran lain untuk kontrol positif (gel Acnes ${ }^{\circledR}$ ) dan kontrol negatif (Basis gel tanpa ekstrak). Masing-masing sediaan gel diambil 0,1 Gram dan dimasukkan pada setiap sumuran kemudian diinkubasi pada suhu $37^{\circ} \mathrm{C}$ selama 24 jam.

\section{Evaluasi Fisik Sediaan Gel}

\section{Uji Organoleptik}

Pengamatan organoleptik dilihat secara langsung bentuk, warna, dan bau dari gel yang dibuat. Gel biasanya jernih dengan konsistensi setengah padat (Ansel, 1989). 
PHARMACON- PROGRAM STUDI FARMASI, FMIPA, UNIVERSITAS SAM RATULANGI,

Volume 8 Nomor 4 November 2019

\section{Uji Homogenitas}

Sediaan gel dioleskan pada sekeping kaca, kemudian diamati bagian yang tidak tercampur. Homogenitas ditunjukkan dengan tidak adanya butiran kasar (Kumesan et al., 2013).

\section{Uji Sineresis}

Sineresis yang terjadi selama penyimpanan diamati dengan menyimpan gel pada suhu $\pm 10^{\circ} \mathrm{C}$ selama 24,48 , dan 72 jam. Masing-masing gel ditempatkan pada wadah untuk menampung air yang ada dalam gel selama penyimpanan. Sineresis dihitung dengan mengukur kehilangan berat selama penyimpanan lalu dibandingkan dengan berat awal gel (Latimer, 2012).

\section{Uji Daya sebar}

Gel ditimbang sebanyak 1 gram diletakkan pada kaca transparan yang berdiameter $15 \mathrm{~cm}$, ditutup dengan kaca lainnya di atasnya dan dibiarkan selama \pm 1 menit. Diameter sebar gel diukur. Setelahnya, ditambahkan beban tambahan seberat $125 \mathrm{~g}$ dan didiamkan selama 1 menit lalu diukur diameter yang konstan. Daya sebar 5-7 cm menunjukkan konsistensi semisolid yang sangat nyaman dalam penggunaan (Garg et al., 2002).

\section{Uji Daya lekat}

Gel ditimbang seberat $0,25 \mathrm{~g}$ dan diletakkan pada gelas obyek, ditutup menggunakan obyek gelas yang lain hingga tertutup sempurna. Gel uji diberi beban 250 g diberikan diatas obyek gelas uji selama 5 menit. Beban seberat 80 g digunakan untuk melepas lekatan kedua obyek gelas menggunakan alat pengukur daya lekat. Waktu yang dibutuhkan untuk melepas obyek gelas dihitung menggunakan alat stopwatch (Marchaban, 2017).

\section{Uji pH}

Pengukuran $\mathrm{pH}$ dilakukan dengan cara mencelupkan $\mathrm{pH}$ meter ke dalam sediaan gel ekstrak daun Kaliandra. $\mathrm{pH}$ sebaiknya memiliki sesuai dengan $\mathrm{pH}$ kulit yaitu 4,5 - 6,5 (Tranggono, 2007).

\section{Uji Stabilitas}

Uji cycling test ini dilakukan sebanyak 6 siklus selama 12 hari. Sediaan gel disimpan pada suhu $\pm 4^{\circ} \mathrm{C}$ selama 24 jam dan suhu $\pm 40^{\circ} \mathrm{C}$ selama 24 jam, proses ini dihitung 1 siklus (Dewi, 2010).

\section{Uji Sterilitas}

Siapkan media Nutrient Agar dilarutkan dalam aquadest menggunakan Erlenmeyer. Media disterilkan dalam autoclave pada suhu $121^{\circ} \mathrm{C}$ selama 15 menit. Tuang media NA ke dalam cawan petri steril dan biarkan media NA sampai memadat. Inokulasikan gel ke dalam media yang telah memadat. Inokulasi dilakukan menggunakan kawat ose yang telah disterilkan dengan cara dibakar pada api cawan bunsen. Kemudian inkubasi cawan petri secara terbalik selama 24 jam pada suhu $40^{\circ} \mathrm{C}$. Amati pertumbuhan mikroorganisme menggunakan bantuan alat colony counter (Das, et al., 2011 ; Ramane, et al., 2013).

\section{HASIL DAN PEMBAHASAN}

Penelitian ini dilakukan dengan membuat suatu formulasi sediaan gel dengan menggunakan bahan aktif yaitu ekstrak etanol daun Kaliandra. Daun ini dipilih karena mengandung tanin, selain tanin daun Kaliandra juga mengandung flavonoid, dan saponin. Dimana senyawasenyawa ini merupakan senyawa yang berpotensi sebagai antibakteri. 
PHARMACON- PROGRAM STUDI FARMASI, FMIPA, UNIVERSITAS SAM RATULANGI,

Volume 8 Nomor 4 November 2019

Hasil pengujian mikrobiologi sediaan gel ekstrak etanol daun Kaliandra bertujuan untuk menguji efektivitas antibakteri sediaan gel untuk mendapatkan formula terbesar.

\section{Antibakteri (mm)}

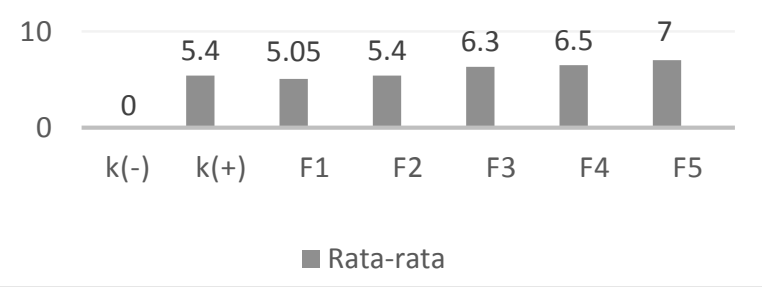

Gambar 1. Hasil Pengujian Mikrobiologi

Hasil dari pengujian berdasarkan gambar diatas, menunjukkan aktivitas antibakteri dengan adanya zona hambat disekitar sumuran. Diameter zona hambat disekitar sumuran diukur menggunakan jangka sorong dengan cara mengukur secara horizontal dan vertikal kemudian hasil yang didapatkan dikurangi diameter sumuran 7 $\mathrm{mm}$. Hasil daya hambat yang dihasilkan rata-rata dari ketiga pengulangan yang dilakukan yaitu terdapat pada konsentrasi $6 \%$ dimana dapat dilihat bahwa gel ekstrak etanol daun kaliandra yaitu konsentrasi $6 \%$ paling besar menghambat aktivitas bakteri Staphylococcus aureus dengan rata-rata yaitu 7,0 $\mathrm{mm}$, dan kontrol positif yaitu 5,4 $\mathrm{mm}$ dan kontrol negatif tidak memberikan daya hambat karena menghasilkan daya hambat sebesar $0 \mathrm{~mm}$. Adanya zona hambat yang terbentuk karena adanya senyawa flavonoid, saponin dan tanin pada daun kaliandra yang mampu menghambat aktivitas bakteri. Daya hambat rata-rata yang dihasilkan gel ekstrak etanol daun kaliandra termasuk kedalam golongan daya hambat sedang sesuai dengan golongan daya hambat menurut Davis dan Stout (1971).
Analisis statistika pada uji antibakteri sediaan gel ekstrak etanol daun Kaliandra konsentrasi $6 \%$ dilakukan one sample test untuk mengetahui perbedaan sebelum dan sesudah cycling test. Dengan hipotesis $\mathrm{H}_{0}$ yaitu tidak memiliki aktivitas antibakteri dan $\mathrm{H}_{1}$ memiliki aktivitas antibakteri. Jika nilai signifikansi $<0,05$ maka $\mathrm{H}_{0}$ ditolak dan jika nilai signifikansi $\geq 0,05$ maka $\mathrm{H}_{0}$ diterima. Hasil nilai signifikansi yang di dapat yaitu 0,003 maka $\mathrm{H}_{0}$ ditolak dan $\mathrm{H}_{1}$ diterima dan dapat disimpulkan bahwa sediaan gel ekstrak etanol daun Kaliandra konsentrasi 6\% memiliki aktivitas antibakteri.

Uji Organoleptik bertujuan untuk mengamati bentuk, warna, dan aroma dari sediaan gel ekstrak daun Kaliandra. Gel yang dihasilkan menunjukan bahwa semua formula gel memiliki bentuk setengah padat yang merupakan karakteristik dari gel pada umumnya. Warna hijau merupakan hasil dari adanya kandungan ekstrak etanol daun Kaliandra, namun gel yang dihasilkan tidak tampak jernih dan tidak tembus cahaya (transparan), hal ini dikarenakan warna esktrak hijau pekat. Hal ini tampak dari perubahan warna dari basis gel yang semula bening menjadi hijau sampai hijau kehitaman. Semakin tinggi kadar konsentrasi ekstrak yang terkandung maka warnanya akan semakin gelap. Semakin tinggi konsentrasi ekstrak maka semakin tercium aroma khas ekstrak etanol daun Kaliandra. Untuk basis gelnya sendiri tidak berbau. Setelah dilakukan penyimpanan tidak terjadi perubahan warna, bentuk, dan bau pada sediaan gel, ini dapat diartikan bahwa gel ekstrak daun Kaliandra memiliki stabilitas yang baik dalam penyimpanan karena tetap sama waktu sebelum penyimpanan dan sesudah penyimpanan.

Uji homogenitas bertujuan untuk melihat dan mengetahui tercampurnya 
PHARMACON- PROGRAM STUDI FARMASI, FMIPA, UNIVERSITAS SAM RATULANGI,

Volume 8 Nomor 4 November 2019

bahan-bahan yang digunakan dalam formula gel, baik bahan aktif maupun bahan tambahan secara merata. Semua formula ini dari sebelum penyimpanan dan sesudah penyimpanan menunjukkan susunan yang homogen yang ditandai dengan tidak terdapat butiran kasar pada gel. Hal ini sesuai dengan persyaratan homogenitas gel yaitu harus menunjukkan dengan tidak adanya butiran kasar (Kumesan et al., 2013).

Uji sineresis merupakan keluarnya air dari dalam sediaan dimana air tidak terikat kuat oleh komponen bahan yang ada. Semakin tinggi sineresis maka semakin cepat lunak tekstur sediaan gel tersebut. Hasil uji sineresis sebelum dan setelah penyimpanan tidak menunjukkan adanya sineresis pada sediaan. Hal ini menunjukkan semua sediaan stabil secara fisik sebelum dan sesudah peyimpanan.

Uji daya sebar dilakukan untuk melihat kemampuan penyebaran gel pada permukaan kulit pada saat pemakaian. Sediaan gel yang baik akan menghasilkan daya sebar sebesar 5-7 cm. Pada konsentrasi $6 \%$ hasil rata-rata yang didapatkan sebelum penyimpanan cukup baik yaitu $5,64 \mathrm{~cm}$, dan setelah penyimpanan pada siklus 6 mendapatkan hasil yaitu $5,96 \mathrm{~cm}$. Dari hasil yang didapat menunjukkan formula sediaan gel memenuhi syarat daya sebar yang baik yaitu 5-7 cm (Garg, et al., 2002).

Analisis statistika pada uji daya sebar sediaan gel ekstrak etanol daun Kaliandra konsentrasi $6 \%$ dilakukan independent $T$ test. Jika nilai signifikansi (2tailed) $\geq 0,05$ maka memiliki perbedaan tidak bermakna sebelum dan sesudah cycling test. Hasil nilai signifikansi (2-tailed) yaitu 0,239 atau >0,05 dan dapat disimpulkan bahwa uji daya sebar sediaan gel ekstrak etanol daun Kaliandra konsentrasi $6 \%$ memiliki perbedaan tidak bermakna sebelum dan sesudah cycling test.
Uji daya lekat dilakukan bertujuan untuk mengetahui kemampuan melekat gel pada permukaan kulit. Tidak ada persyaratan khusus mengenai daya lekat sediaan gel, namun sebaiknya daya lekat sediaan gel yaitu lebih dari 1 detik (Zats, 1996). Hasil daya lekat gel konsentrasi $6 \%$ waktu yang di dapat yaitu 1,01 detik dan setelah dilakukan penyimpanan pada siklus 6 waktu yang didapat yaitu 1,14 detik. Menurut Ansel (1989) kemampuan gel melekat pada kulit dapat mempengaruhi efek terapi yang dihasilkan. Semakin lama sediaan melekat pada kulit maka efek terapi yang diberikan oleh sediaan akan lebih lama pula sebab sediaan akan lebih lama kontak dengan kulit.

Analisis statistika pada uji daya lekat sediaan gel ekstrak etanol daun Kaliandra konsentrasi $6 \%$ dilakukan independent $T$ test. Jika nilai signifikansi (2-tailed) $\geq 0,05$ maka memiliki perbedaan tidak bermakna sebelum dan sesudah cycling test. Hasil nilai signifikansi (2-tailed) yaitu 0,447 atau >0,05 dan dapat disimpulkan bahwa uji daya lekat sediaan gel ekstrak etanol daun Kaliandra konsentrasi $6 \%$ memiliki perbedaan tidak bermakna sebelum dan sesudah cycling test.

Uji $\mathrm{pH}$ bertujuan untuk mengetahui keamanan sediaan saat digunakan agar tidak mengiritasi kulit (Anief, 2004). Nilai pH yang terlalu asam dan basa juga dapat mengiritasi kulit ketika diaplikasikan secara topikal. Pengujian $\mathrm{pH}$ pada sediaan gel menggunakan $\mathrm{pH}$ meter. Kestabilan $\mathrm{pH}$ merupakan salah satu parameter penting yang menentukan stabil atau tidaknya suatu sediaan. Dari hasil yang didapat nilai $\mathrm{pH}$ dengan konsentrasi $6 \%$ sebelum penyimpanan yaitu 5,66 dan setelah penyimpanan nilai $\mathrm{pH}$ dari siklus 1-4 terjadi kenaikan dan penurunan yang bervariasi selama pengujian. Pada pengujian $\mathrm{pH}$ sediaan gel masih bersifat aman karena 
PHARMACON- PROGRAM STUDI FARMASI, FMIPA, UNIVERSITAS SAM RATULANGI,

Volume 8 Nomor 4 November 2019

masih berada dibawah $\mathrm{pH}$ netral sehingga tidak terlalu bersifat basa, dan tidak menyebabkan iritasi jika diaplikasikan pada kulit. Nilai pH terlalu asam dapat menyebabkan kulit gatal-gatal dan bersisik, dan nilai $\mathrm{pH}$ melampaui 7 dikhawatirkan dapat menyebabkan iritasi kulit (Gozali, 2009).

Analisis statistika pada uji $\mathrm{pH}$ sediaan gel ekstrak etanol daun Kaliandra konsentrasi $6 \%$ dilakukan independent $T$ test. Jika nilai signifikansi (2-tailed) $\geq 0,05$ maka memiliki perbedaan tidak bermakna sebelum dan sesudah cycling test, dan jika nilai (2-tailed) $<0,05$ maka memiliki perbedaan bermakna sebelum dan sesudah cycling test. Hasil nilai signifikansi (2tailed) yaitu 0,000 atau $<0,05$ dan dapat disimpulkan bahwa uji $\mathrm{pH}$ sediaan gel ekstrak etanol daun Kaliandra konsentrasi $6 \%$ memiliki perbedaan bermakna sebelum dan sesudah cycling test.

Uji sterilitas bertujuan untuk mengetahui suatu sediaan dimana sediaan harus dalam keadaan steril, atau suatu sediaan tersebut harus bebas dari mikroorganisme. Pengujian sterilitas yang dilakukan dengan melakukan pengamatan terdapat atau tidaknya mikroorganisme pada gel yang telah dioleskan pada media nutrien agar dan telah diinkubasi pada suhu $36^{\circ} \mathrm{C}$ selama 24 jam. Dari hasil pengamatan didapati bahwa sediaan gel ekstrak daun kaliandra tidak terdapat mikroorganisme pada suatu sediaan. Hal ini menunjukkan sediaan gel steril karena tidak ditemukan pertumbuhan mikroorganisme.

\section{KESIMPULAN}

Berdasarkan hasil penelitian sediaan gel ekstrak etanol daun Kaliandra pada konsentrasi $6 \%$ memiliki efek antibakteri terhadap Staphylococcus aureus dengan diameter rata-ratanya $7,0 \mathrm{~mm}$ yang dikategorikan sedang dan kualitas sediaan gel ekstrak etanol daun Kaliandra konsentrasi $6 \%$ sangat baik pada beberapa evaluasi fisik yang dilakukan seperti uji organoleptik, uji homogenitas, uji sineresis, uji daya lekat, uji daya sebar, uji pH dan uji sterilitas.

\section{SARAN}

Disarankan kepada penelitian selanjutnya untuk perlu dilakukan evaluasi fisik yang belum dilakukan dalam penelitian ini yaitu uji viskositas dan uji iritasi.

\section{DAFTAR PUSTAKA}

Anief, Moh. 2004. Ilmu Meracik Obat. Gadjah Mada University Press, Yogyakarta.

Ansel, H.C. 1989. Pengantar Bentuk Sediaan Farmasi. Diterjemahkan oleh Farida Ibrahim, Asmanizer, Iis Aisyah. Edisi Ke-IV, 255-271, 607-608, 700. UI Press, Jakarta.

Ansel, H.C. 2005. Pengantar Bentuk Sediaan Farmasi, diterjemahkan oleh Ibrahim, F., Edisi IV, 605-619. UI Press, Jakarta.

A Wawan dan Dewi. 2010. Teori dan Pengukuran dan Sikap Perilaku Manusia. Nuha Medika, Yogyakarta.

Das, S., Halder, P.K., dan Pramanik, G., 2011. Formulation and Evaluation Of Herbal Gel Countaining Clerodendron Infortunatum Leaves Extract. Int $J$ Of Pharm Tech Res. 1:140-3.

Davis, W. W., T.R. Stout. 1971. Disc plate method of microbiological assay. 
PHARMACON- PROGRAM STUDI FARMASI, FMIPA, UNIVERSITAS SAM RATULANGI,

Volume 8 Nomor 4 November 2019

Journal of microbiology. 22: 659665.

Garg, A.D., Aggarwal, S. Garg., and A.K. Sigla. 2002. Spreading of Semisolid Formulation : An Update. Pharmaceutical Tecnology. September : 84-102.

Gozali, D., Abdassah, M. Subghan, A. AlLathiefah, S. 2009. Formulasi Krim Pelembab Wajah yang Mengandung Tabir Surya Nanopartikel Zink Oksida Salut Silikon. Bandung Farmaka.

Jawetz, E., Melnick, J.L., Adelberg, E.A. 2005. Mikrobiologi Kedokteran, 315326, 352-360. Jakarta : Penerbit Salemba Medika.

Kumesan YAN., Yamlean PVY., dan Supriati. 2013. Formulasi dan Uji Aktivitas Antijerawat Ekstrak Umbi Bakung (Crinum Asiaticum L.) Terhadap Bakteri Staphylococcus aureus Secara In Vitro. Pharmacon. 2(2).

Latimer G (editor). 2012. Official Methods of Analysis of AOAC International, $19^{\text {th }}$ Edition.

Marchaban, Fudholi, A., Saifullah, T,N., Martien, R., Kuswahyuning, R., Bestari, A.N., dkk. 2017. Teknologi Formulasi Sediaan Cair Semi Padat, 3rd ed. Fakultas Farmasi UGM, Yogyakarta.

Radji, M. 2011. Buku Ajar Mikrobiologi Panduan Mahasiswa Farmasi \& Kedokteran. Jakarta : Penerbit Buku Kedokteran EGC.
Ramane, S.B., Syed, V.N., and Biyani, K.R. 2013. Evaluation of Wound Healing Activity of Polyherbal Gel-A Novel Herbal Formulation. International Journal of Research In Pharmaceutical and Biomedical Sciences. 4:788-794.

Tranggono, R.I., Latifah, F. 2007. Buku Pegangan Ilmu Pengetahuan Kosmetik. Gramedia Pustaka Umum, Jakarta.

Warsa, U. C. 1994. Kokus Positif Gram, dalam Buku Ajar Mikrobiologi Kedokteran, Edisi Revisi, Staf Pengajar Fakultas Kedokteran Universitas Indonesia, 103. Jakarta : Binarupa Aksara.

Wyatt, E., Sutter, S.H., Drake, L.A. 2001. Dermatology Pharmacology, in Goodman and Gilman's The Pharmacological basic of Therapeutics. Hardman, J. G., limbird, L. E., Gilman, A. G., (editor), 10 th, 1801-1803, McGraw-hill, New York.

Zatz, J. L., dan Kushla, G.P., Gels, Lieberman, H.A., Lachman, L., Schwatz, J. B. 1996. Pharmaceutical Dosage Form : Dysperse System Vol. 2. $2^{\text {nd }}$ Ed., 399-418, Marcell Dekker Inc., New York. 